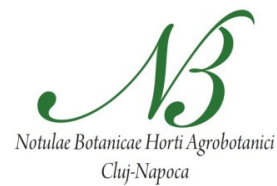

\title{
Investigation of Comparative Regulation on Antioxidant Enzyme System under Copper Treatment and Drought Stress in Maize (Zea mays L.)
}

\author{
Hatice CETINKAYA, Burcu SECKIN DINLER*, Eda TASCI
}

\author{
Sinop University, Faculty of Arts and Sciences, Department of Biology, Sinop, Turkey; bseckin@sinop.edu.tr (*corresponding author)
}

\begin{abstract}
The present study was conducted to present the responses of drought-sensitive 'Shemal' and drought-tolerant '71MAY69' maize cultivars under drought condition $(20 \%$ Polyethylene glycol, $-0.40 \mathrm{MPa})$ and three different copper concentrations $(0.5$ $\mathrm{mM}, 1 \mathrm{mM}, 1.5 \mathrm{mM} \mathrm{CuSO} \cdot 5 \mathrm{H}_{2} \mathrm{O}$ ) for 5 days to determine the enzymatic responses of copper treatment in maize leaves. Copper treatments alone did not change stomatal conductance, relative water content, malondialdehyde, proline, hydrogen peroxide content and abscisic acid level according to control groups. Combined treatment (drought and copper) alleviated the damage of PEG- induced drought stress in maize leaves. Superoxide dismutase (SOD), catalase (CAT), glutatione reductase (GR) activity increased and glutathione $-S$ transferase (GST) activity decreased, while ascorbate peroxidase (APX) activity did not change under drought stress in the tolerant cultivar. SOD, CAT and APX were decreased and GST activities were increased while GR did not change in 'Shemal'. Also SOD, APX and CAT activity increased by copper treatment alone in both cultivars. Otherwise combined treatment increased SOD, APX and CAT activity at all concentrations, but GR and GST activity increased only by $(\mathrm{PEG}+1.5 \mathrm{mM})$ treatment when compared with PEG treatment alone in sensitive ones. As a result, exogenous copper alleviated drought stress, while it induced an oxidative damage by increasing antioxidant enzyme activities differently from drought tolerance. Copper tolerance in maize is not a common response of its defense mechanism because of different response to copper and drought in the same cultivar.
\end{abstract}

Keywords: antioxidant enzyme, copper, maize, drought stress

Abbreviations: SOD: Superoxide dismutase; CAT: Catalase; GST: glutathione $-S$ transferase; GR: Glutathione reductase; APX: Ascorbate peroxidase; MDA: Malondialdehyde; ABA: Abscisic acid; ROS: reactive oxygen species; $\mathrm{H}_{2} \mathrm{O}_{2}$ : $\mathrm{Hydrogen}$ peroxide; RWC: Relative water content; PEG: Polyethylene glycol; EC: Enzyme Commission

\section{Introduction}

Copper $(\mathrm{Cu})$ is an essential micronutrient for the growth and development of plants. Cu plays an important role in plant metabolism like respiration, photosynthesis, protein and carbohydrate metabolism (Droppa and Horvath, 1990), but becomes toxic at high concentrations (Gaetke and Chow, 2003).

Excess copper can interfere with protein function, enzyme activity, and membrane integrity (Alaoui-Sosse et al., 2004). It can induce secondary oxidative stress by catalyzsing the formation of reactive oxygen species such as hydroxyl radical, superoxide anion radical and singlet oxygen (Hall, 2002). These reactive oxygen species (ROS), including superoxide radicals, hydrogen peroxide and hydroxyl radicals, are highly reactive and can cause serious damage to membrane lipids, proteins and nucleic acids (Wang et al., 2004) as well as signalling dysfunctions and other metabolic disturbances (Yruela, 2005).
Plants have enzymatic defense system against oxidative stress. SOD (EC 1.15.1.1), CAT (EC 1.11.1.6), APX (EC 1.11.1.11), GR (EC 1.6.4.2) and GST (EC 2.5.1.18) play role of scavenging these ROS. It is well known that the negative effects of oxidative damage could be alleviated by these enzymes activities. There are many studies related to stress tolerance and antioxidant enzyme in plant species (Gill and Tuteja, 2010). With regard to copper stress, controversial studies have been reported stating that this metal induced antioxidant enzymes in different plant species, concentrations and durations of metal exposure (Rama and Prasad, 1998). Early studies showed that excessive $\mathrm{Cu}$ reduced cell increment of many plant species and root biomass of maize (Ouzounidou et al., 1995).

The mechanisms through which copper induces antioxidative response in plants are not clear. Sgherri et al. (2001) reported that it is a question whether the difference in $\mathrm{Cu}$ sensitivity observed between two cultivars is related to their co-tolerance towards drought stress. To evaluate this, 
this study was aimed to point out the comparative regulation of antioxidant enzymes under copper treatment with stress (drought) as a control in drought-sensitive and tolerant maize leaves. SOD, APX, CAT, GR and GST enzymes activities and hydrogen peroxide, MDA, ABA, proline content, RWC, stomatal conductance and endogenous copper content were determined comparatively.

\section{Materials and methods}

\section{Plant growth and experimental design}

Seeds belonging to maize drought-sensitive 'Shemal' cultivar and drought-tolerant '71MAY69' cultivar were used as the biological material of this present study. The seeds were sown in plastic pots, each of which (width $20 \mathrm{~cm}$, length 12 $\mathrm{cm}$, height $18 \mathrm{~cm}$ ) contains 30-40 seeds and the mixture of soil: clay: clay-loam in the ratio of $2: 1: 1, \mathrm{pH}: 6.5)$. Seeds were placed in the dark for 5 days for germination. The germinated seeds were then subjected to $16 \mathrm{~h}$ light $/ 8 \mathrm{~h}$ dark periods. They were watered with full strength Hoagland solution (Hoagland and Arnon, 1950) and grown at $25 \pm 4{ }^{\circ} \mathrm{C}$ until the seedling stage. 8 day old seedlings were divided into control (1), $20 \%$ PEG (2), Cu $0.5 \mathrm{mM}$ (3), Cu $1 \mathrm{mM}$ (4), Cu $1.5 \mathrm{mM}$ (5), 20\% PEG+Cu $0.5 \mathrm{mM}$ (6), 20\% PEG+Cu $1 \mathrm{mM}$ (7), 20\% $\mathrm{PEG}+\mathrm{Cu} 1.5 \mathrm{mM}(8)$ groups and watered with Hoagland solution for 5 days. Then, the seedlings were harvested on the 5 th day and the samples were preserved at $-20^{\circ} \mathrm{C}$. The osmotic potential with PEG was $-0.40 \mathrm{MPa}$.

\section{Analyses \\ Measurement of bydrogen peroxide and malondialdebyde content}

The $\mathrm{H}_{2} \mathrm{O}_{2}$ content was determined according to Velikova et al. (2000). Fresh leaves (0.1 g) were homogenized in $5 \mathrm{ml}$ of $0.1 \%$ trichloroacetic acid (TCA) and centrifuged at 12,000 $\mathrm{rpm}$ for $15 \mathrm{~min}$. The supernatant $(0.5 \mathrm{ml})$ was then mixed with $0.5 \mathrm{ml}$ of buffer $(10 \mathrm{mM}$ potassium phosphate, $\mathrm{pH} 7)$ and $1 \mathrm{ml}$ of $1 \mathrm{M} \mathrm{KI}$. The absorbance reading was taken at $390 \mathrm{~nm}$. The level of lipid peroxidation in leaf samples was determined in terms of the malondialdehyde (MDA) content according to the method specified by Madhava and Sresty (2000). The MDA content, an end-product of lipid peroxidation, was determined by using the thiobarbituric acid reaction. The MDA concentration was calculated from the absorbance at $532 \mathrm{~nm}$, and measurements were corrected for nonspecific turbidity by subtracting the absorbance at $600 \mathrm{~nm}$. An extinction coefficient of $155 \mathrm{mM}^{-1} \mathrm{~cm}^{-1}$ was used to determine the MDA concentration.

\section{Relative water content and stomatal conductance assay}

The relative water content (RWC) was calculated in accordance with Smart and Bingham (1974). Harvested leaves were weighed to determine their fresh weights (FW). The seedlings were floated on de-ionized water for $5 \mathrm{~h}$ under low irradiance and then the turgid tissue was quickly blotted to remove excess water and their turgid weights (TW) were determined. Dry weights (DW) were determined after the leaves were dried in an oven at $70{ }^{\circ} \mathrm{C}$ for $72 \mathrm{~h}$. Stomatal conductance was measured on the 0th and 5th day of stress treatment using a portable steady-state porometer (SC-1). The data were collected from six sample leaves per replicate.
Measurement of $C u^{2+}$ ion content

The $\mathrm{Cu}^{2+}$ content was obtained by wet oxidation of dried leaf tissue with nitric and perchloric acids in accordance with the method adapted by Hanlon (1998) (AAS), Kacar and Inal (2008) (AAS, ICP-OES). The digest was diluted with $0.1 \mathrm{~N}$ perchloric acid, and $\mathrm{Cu}$ concentrations were determined by atomic absorption spectrophotometry.

\section{Measurement of ABA level}

ABA content levels were determined in accordance with Flores et al. (2011) with an UHPLCMS/MS. Stock standard solutions of individual compounds (with concentrations ranging from 200 to $300 \mathrm{mg} / \mathrm{L}$ ) were prepared by exact weighing of the powder and they were dissolved in methanol (HPLC-grade).

\section{Measurement of proline content}

The proline contents of leaves were determined according to Claussen (2005). For each treatment, $0.5 \mathrm{~g}$ leaf sample was ground in a mortar after addition of a small amount of glasspowder and $5 \mathrm{~mL}$ of a $3 \%(\mathrm{w} / \mathrm{v})$ aqueous sulfosalicylic acid solution. The homogenate was filtered through two layers of glass-fibers. To the filtrate $(1 \mathrm{~mL})$, glacial acetic acid and ninhydrin reagent $(1 \mathrm{ml}$ each) were added. The closed test tubes containing the reaction mixture were kept in a boiling water bath for $1 \mathrm{~h}$ before the reaction was terminated at room temperature $\left(22^{\circ} \mathrm{C}\right)$ for $5 \mathrm{~min}$. The absorbance of the reaction mixture was determined at $546 \mathrm{~nm}$. The proline concentration was determined from a standard curve and calculated on freshweight basis ( $\mu$ g proline $\mathrm{g}^{-1} \mathrm{FW}$ ).

\section{Antioxidant enzyme and isoenzyme activity}

The superoxide dismutase (EC 1.15.1.1) activity was assayed by its ability to inhibit the photochemical reduction of nitrotetrazolium blue chloride (NBT) at $560 \mathrm{~nm}$ (Beauchamp and Fridovich, 1971). Equal amounts of protein were subjected to nondenaturing polyacrylamide gel electrophoresis (PAGE) as described by Laemmli (1970), except that sodium dodecyl sulfate was omitted. For the separation of SOD isoenzymes, $4.5 \%$ stacking and $12.5 \%$ separating gels under constant current $(60 \mathrm{~mA})$ at $4^{\circ} \mathrm{C}$ were used. SOD activity was detected by photochemical staining with riboflavin and NBT as described by Beauchamp and Fridovich (1971). Gels stained for SOD activities were photographed with an Image Acquisition and Analysis Software (4.6.00.0; UVP Biolmaging systems, UK). In densitometric analyses of SOD activities of control plants were taken as $100 \%$ and $\%$ of control values for each treatment are shown. The values are the average of data from 3 independent gels. The ascorbate peroxidase (EC 1.11.1.11) activity was measured according to Nakano and Asada (1981). The assay depended on the decrease in absorbance at $290 \mathrm{~nm}$ as the ascorbate was oxidized. The reaction mixture contained $50 \mathrm{mM} \mathrm{Na}$-phosphate buffer $(\mathrm{pH}$ 7.0), $50 \mathrm{mM}$ ascorbate, $0.1 \mathrm{mM}$ EDTA Na2, $1.2 \mathrm{mM} \mathrm{H}_{2} \mathrm{O}_{2}$, and $0.1 \mathrm{ml}$ of enzyme extract in a final assay volume of $1 \mathrm{ml}$. The concentration of oxidized ascorbate was calculated by using an extinction coefficient of $2.8 \mathrm{mM}^{-1} \mathrm{~cm}^{-1}$. One unit of APX was defined as $1 \mathrm{mmol} \mathrm{m}^{-1}$ ascorbate oxidized $\mathrm{min}^{-1}$. The catalase (EC 1.11.1.6) activity was assayed in a reaction mixture $(2 \mathrm{ml})$ containing $50 \mathrm{mM} \mathrm{K}$-phosphate buffer $(\mathrm{pH}$ 7.0). Then, $12.2 \mathrm{mM} \mathrm{H}_{2} \mathrm{O}_{2}$ was added, and the reaction was 
365

started by adding $100 \mu \mathrm{l}$ supernatant. The activity was determined by monitoring the degradation of $\mathrm{H}_{2} \mathrm{O}_{2}$ at $240 \mathrm{~nm}$ over 2 min against a supernatant-free blank. Enzyme-specific activities were expressed as $\mu \mathrm{mol}$ of $\mathrm{H}_{2} \mathrm{O}_{2}$ oxidized min-1mg-1 protein (Bergmeyer, 1970). GR (EC 1.6.4.2) activity was measured according to Foyer and Halliwell (1976). The assay medium contained $25 \mathrm{mM}$ Na-phosphate buffer ( $\mathrm{pH} 7.8), 0.5$ $\mathrm{mM}$ GSSG, $0.12 \mathrm{mM}$ NADPH.Na, and $0.1 \mathrm{ml}$ enzyme extract in a final assay volume of $1 \mathrm{ml}$. NADPH oxidation was followed at $340 \mathrm{~nm}$. Activity was calculated using the extinction coefficient of NADPH $\left(6.2 \mathrm{mM}^{-1} \mathrm{~cm}^{-1}\right)$. One unit of GR was defined as $1 \mathrm{mmol} \mathrm{ml}^{-1}$ GSSG reduced $\mathrm{min}^{-1}$. The specific enzyme activity for all enzymes was expressed as in unit $\mathrm{mg}^{-1}$ protein. GST (EC 2.5.1.18) activity was determined by the method of Habig et al. (1974) by following the increase in absorbance at $340 \mathrm{~nm}$ due to the formation of the conjugate 1chloro-2,4- dinitrobenzene (CDNB) using as substrate at the presence of reduced glutathione (GSH).

\section{Statistical analysis}

Statistical variance analysis of the data was performed using ANOVA and differences among treatments were compared using Tukey's post-hoc analysis with least significant differences at the $5 \%$ level.

\section{Results and discussion}

Under drought stress, a reduction in RWC was a common response in plants (Pérez-Pérez et al., 2007). In the results, PEG treatment reduced RWC in both cultivars when compared with the control samples (Tab. 1) Reduction in RWC results in loss of turgidity, which leads to stomatal closure and reduced photosynthetic rates (Kramer and Boyer 1995). Parallel to this, in our findings, tolerant cv. '71MAY69' showed higher reduction (23.7\%) in stomatal conductance than in the sensitive one $(9 \%)$ to prevent water loss (Fig. 3). However, copper treatment alone did not change RWC content, when compared with the control group. Parallel to this result, Chen et al. (2001) observed no change in RWC under $\mathrm{Cu}$ treatment in rice leaves. In contrast, excess copper treatment reduced RWC in sunflower leaves as reported by Kastori et al. (2008). In this work, stomatal conductance was also not affected under copper treatment alone, in parallel to the results of RWC. Otherwise, combined treatment (PEG $+0.5 \mathrm{mM}, 1 \mathrm{mM}$, $1.5 \mathrm{mM}$ ) increased RWC according to PEG treatment alone, but the highest alleviation was under PEG+ $1 \mathrm{mM}$ $\mathrm{Cu}, \mathrm{PEG}+1.5 \mathrm{mM} \mathrm{Cu}$ in cv. 'Shemal'. Accordingly, stomatal conductance was nearly the same as control levels under combined treatment (Fig. 3). It could be explained that copper protects leaves from dehydration by increasing compatible solutes such as proline ( $\mathrm{Ku}$ et al., 2012). Interestingly, copper treatment alone did not change proline level, while combined treatment increased proline content in both cultivars (Fig. 5). These results showed us that proline accumulation could be related only with drought tolerant in maize leaves.

ABA is produced under dehydration conditions and plays pivotal roles in response to drought stress (Shinozaki and Yamaguchi-Shinozaki, 2000). Direct correlation between ABA content and stomatal conductance has been demonstrated (Socias et al., 1997). In the present study, ABA level was increased (51.69\% and $45.4 \%)$ by drought stress in both cultivars and this could lead to stomatal closure (Fig. 4). These results are in agreement with the reports of Garcia-Mata and Lamattina (2001) and Bright et al. (2006). Otherwise, copper treatment alone did not change the endogenous ABA level. In contrast, Zengin and Kirbag (2007) reported that excess copper treatment increased $\mathrm{ABA}$ content in sunflower. As mentioned before, stomatal conductance did not change under combined treatment in both cultivars according to PEG treatment alone. But combined treatment increased ABA level according to PEG treatment alone in 'Shemal', while it decreased in '71MAY69'. It could be explained that the increase in ABA accumulation was not efficient to close stomata in such cells and this also determines that there was no stress under the combined treatment. PEG treatment induces ABA level under combined treatment independent of the copper effect. As in earlier works (Chen et al., 2001), we demonstrated that copper treatment increased proline content independent of ABA accumulation. In this study, alone copper treatment did not cause any water stress in maize leaves.

MDA is a product of lipid peroxidation; elevation in MDA content determines cell wall damage. In this study, the results showed that PEG increased oxidative damage in both cultivars (18.95\% and 43.8\%) (Fig. 2). Many reports indicate that drought stress induced MDA content in leaves and roots (Reddy et al., 2004). Otherwise, in results, copper treatment alone in all concentrations did not lead to change in MDA content. This result could be explained by the fact that copper concentrations used in the experiment did not induce oxidative damage by inducing antioxidant enzymes in maize leaves. These results are also in agreement with Posmyk et al. (2009) who determined that higher copper concentration $(2.5 \mathrm{mM})$ increased oxidative damage in red cabbage seedlings. Similarly, Fidalgo et al. (2013) observed that enhanced lipid peroxidation in Solanum nigrum L. roots and leaves depend on $\mathrm{Cu}$ concentrations. Apart from this, we determined that MDA level reduced under combined treatment by $52 \%$ in 'Shemal' (PEG+1 $\mathrm{mM} \mathrm{Cu}$ ) and $42 \%$ in ' $71 \mathrm{MAY} 69$ ' (PEG+1.5 mM Cu) (Fig. 2). These findings imply that copper concentrations used in this work ( $1 \mathrm{mM}$ and $1.5 \mathrm{mM}$ ) were effective to protect maize leaves from drought damage. Regarding $\mathrm{H}_{2} \mathrm{O}_{2}$, PEG treatment increased hydrogen peroxide levels in both cultivars. Similar to our results, there was increased in hydrogen peroxide level observed in maize (Chung et al., 2011) and barley (Hossain, 2013) under drought stress.

In this work, copper treatment did not affect the $\mathrm{H}_{2} \mathrm{O}_{2}$ content in both cultivars, but combined treatment (1.5 $\mathrm{mM}$ ) reduced (34.1\% and 67.3\%) $\mathrm{H}_{2} \mathrm{O}_{2}$ content, when compared with PEG treatment alone (Fig. 1). In contrast to our results, 50 and $100 \mu \mathrm{M}$ copper treatment increased hydrogen peroxide content in rice leaves grown in hydroponic culture (Thounaojan, 2012). It could be suggested that copper concentrations showed the same reaction within $\mathrm{H}_{2} \mathrm{O}_{2}$ parallel to MDA results.

SOD (EC1.15.1.1) catalyzes the dismutation of two molecules of superoxide into oxygen and hydrogen peroxide (Fridovich, 1975), the first step in ROS scavenging systems. 
In this study, SOD enzyme activity increased in '71MAY69' by PEG treatment, but decreased in cv. 'Shemal', when compared with the control samples (Fig. 6). Our results are consistent with other studies reporting increased SOD activity in response to drought stress in sunflower (Gunes et al., 2008). In our results, increased copper concentration induced it in '71MAY69', but the highest induction (2.5 fold) was at $1.5 \mathrm{mM}$ in 'Shemal' according to the control group. Otherwise, the induction of SOD activity was not changed between 0.5 and $1 \mathrm{mM}$ treatments in 'Shemal'. These results are parallel to the report of Tanyolaç et al. (2007) who determined that $1.5 \mathrm{mM}$ copper treatment

Tab. 1. Effects of copper treatment under drought stress on relative water content (RWC) (\%) in tolerant '71May69' and sensitive 'Shemal' maize (Zea mays) cultivars

\begin{tabular}{|c|c|c|c|}
\hline \multirow{2}{*}{\multicolumn{2}{|c|}{ Treatments* }} & \multicolumn{2}{|c|}{ Cultivars } \\
\hline & & '71 May 69' & 'Shemal' \\
\hline \multirow{8}{*}{ RWC (\%) } & Control & $92.48 \pm 3.12^{b}$ & $94.09 \pm 1.95^{b}$ \\
\hline & PEG & $87.84 \pm 4.74^{a}$ & $90.68 \pm 5.07^{\mathrm{a}}$ \\
\hline & $0.5 \mathrm{mM} \mathrm{Cu}$ & $92.79 \pm 1.73^{\mathrm{b}}$ & $92.44 \pm 4.17^{\mathrm{b}}$ \\
\hline & $1 \mathrm{mM} \mathrm{Cu}$ & $91.85 \pm 3.85^{\mathrm{b}}$ & $94.60 \pm 2.37^{\mathrm{b}}$ \\
\hline & $1.5 \mathrm{mM} \mathrm{Cu}$ & $91.80 \pm 3.07^{\mathrm{b}}$ & $94.07 \pm 1.39^{\mathrm{b}}$ \\
\hline & $\mathrm{PEG}+0.5 \mathrm{mM} \mathrm{Cu}$ & $90.54 \pm 1.01^{b}$ & $92.94 \pm 2.52^{b}$ \\
\hline & PEG+1 mM Cu & $90.7 \pm 4.13^{b}$ & $93.30 \pm 2.54^{\mathrm{b}}$ \\
\hline & $\mathrm{PEG}+1.5 \mathrm{mM} \mathrm{Cu}$ & $91.12 \pm 1.97^{b}$ & $93.89 \pm 3.76^{\mathrm{b}}$ \\
\hline
\end{tabular}

Tab. 2. Effects of copper treatment under drought stress on $\mathrm{Cu}^{2+}(\mathrm{ppm})$ in tolerant '71May69' and sensitive 'Shemal' maize (Zea mays) cultivars

\begin{tabular}{|c|c|c|c|}
\hline & \multirow{2}{*}{ Treatments* } & \multicolumn{2}{|c|}{ Cultivars } \\
\hline & & '71 May 69' & 'Shemal' \\
\hline \multirow{8}{*}{$\mathrm{Cu}^{2+}(\mathrm{ppm})$} & Control & $7.3 \pm 0.02^{\mathrm{a}}$ & $13.8 \pm 0.05^{\mathrm{b}}$ \\
\hline & PEG & $7.7 \pm 0.04^{a}$ & $7.7 \pm 0.005^{\mathrm{a}}$ \\
\hline & $0.5 \mathrm{mM} \mathrm{Cu}$ & $13.4 \pm 0.05^{b}$ & $15.9 \pm 0.02^{\mathrm{a}}$ \\
\hline & $1 \mathrm{mM} \mathrm{Cu}$ & $11.7 \pm 0.02^{b}$ & $15.9 \pm 0.03^{b}$ \\
\hline & $1.5 \mathrm{mM} \mathrm{Cu}$ & $23 \pm 0.05^{c}$ & $39.7 \pm 0.04^{c}$ \\
\hline & $\mathrm{PEG}+0.5 \mathrm{mMCu}$ & $20.5 \pm 0.05^{c}$ & $29.6 \pm 0.03^{c}$ \\
\hline & PEG+1 mMCu & $19.8 \pm 0.01^{c}$ & $23.7 \pm 0.04^{c}$ \\
\hline & $\mathrm{PEG}+1.5 \mathrm{mMCu}$ & $21 \pm 0.01^{\mathrm{c}}$ & $20.7 \pm 0.09^{c}$ \\
\hline
\end{tabular}

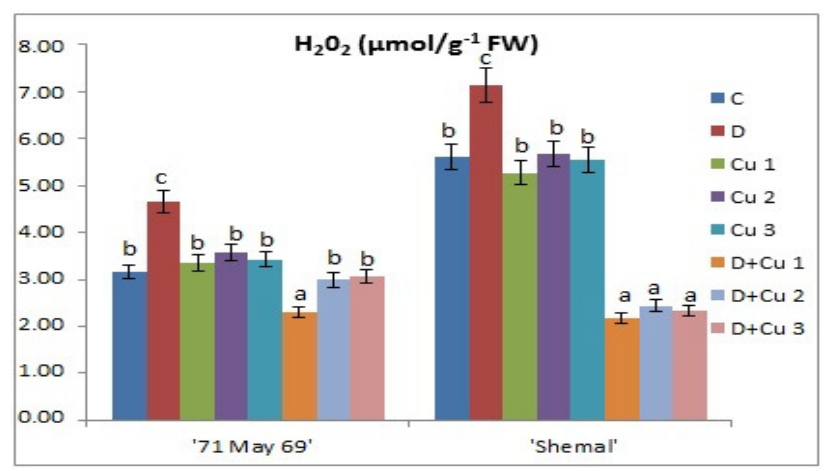

Fig. 1. Effects of copper treatment under drought stress on hydrogen peroxide $\left(\mathrm{H}_{2} \mathrm{O}_{2}\right)$ content in tolerant ' $71 \mathrm{May} 69$ ' and sensitive 'Shemal' maize (Zea mays) cultivars. Control group (C), 20\% PEG (D), Cu 0.5 mM (Cu1), Cu 1 mM (Cu2), Cu $1.5 \mathrm{mM}$ (Cu3), 20\% PEG+Cu $0.5 \mathrm{mM}(\mathrm{D}+\mathrm{Cu} 1), 20 \%$ $\mathrm{PEG}+\mathrm{Cu} 1 \mathrm{mM}(\mathrm{D}+\mathrm{Cu} 2), 20 \% \mathrm{PEG}+\mathrm{Cu} 1.5 \mathrm{mM}(\mathrm{D}+\mathrm{Cu} 3)$. Columns with different letters are significantly different $(\mathrm{P}<$ $0.05)$ values

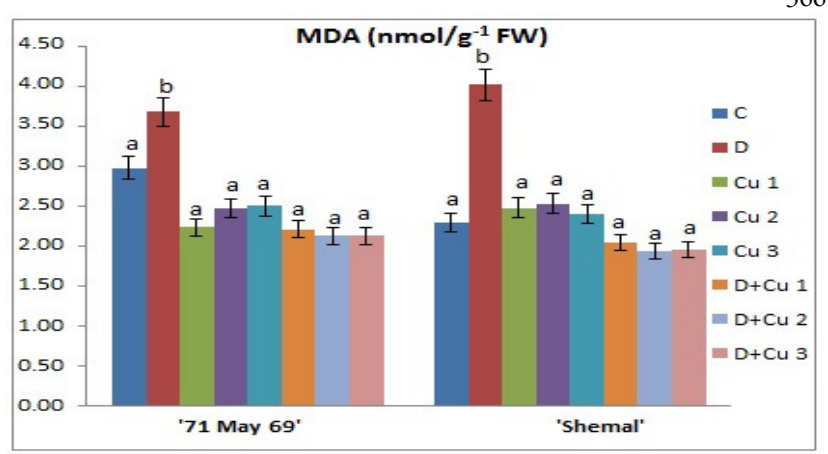

Fig. 2. Effects of copper treatment under drought stress on malondialdehyde (MDA) content in tolerant '71May69' and sensitive 'Shemal' maize (Zea mays) cultivars. Control group (C), 20\% PEG (D), Cu 0.5 mM (Cu1), Cu 1 mM (Cu2), Cu 1.5 mM (Cu3), 20\% PEG+Cu $0.5 \mathrm{mM}$ (D+Cu1), 20\% PEG+Cu $1 \mathrm{mM}$ (D+Cu2), 20\% $\mathrm{PEG}+\mathrm{Cu} 1.5 \mathrm{mM}(\mathrm{D}+\mathrm{Cu} 3)$. Columns with different letters are significantly different $(\mathrm{P}<0.05)$ values

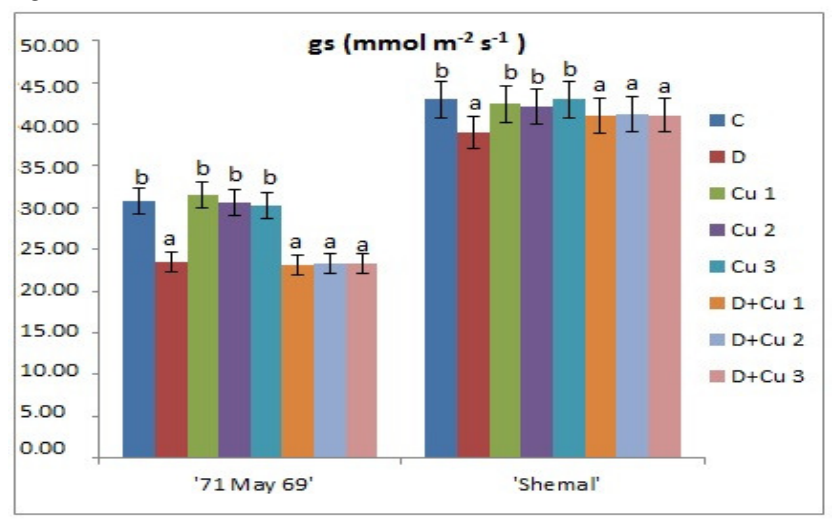

Fig. 3. Effects of copper treatment under drought stress on stomatal conductance (gs) in tolerant '71May69' and sensitive 'Shemal' maize (Zea mays) cultivars. Control group (C), 20\% PEG (D), Cu $0.5 \mathrm{mM}$ (Cu1), Cu 1 mM (Cu2), Cu 1.5 mM (Cu3), 20\% PEG+Cu 0.5 mM (D+Cu1), 20\% PEG+Cu $1 \mathrm{mM}(\mathrm{D}+\mathrm{Cu} 2), 20 \% \mathrm{PEG}+\mathrm{Cu} 1.5 \mathrm{mM}$ $(\mathrm{D}+\mathrm{Cu} 3)$. Different letters represent significantly different $(\mathrm{P}<0.05)$ values

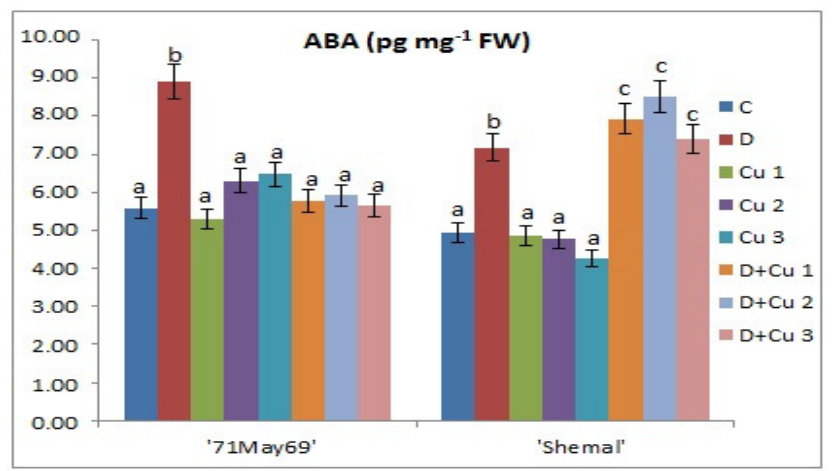

Fig. 4. Effects of copper treatment under drought stress on abscisic acid (ABA) content in tolerant '71May 69' and sensitive 'Shemal' maize (Zea mays) cultivars. Control group (C) 20\% PEG (D), Cu 0.5 mM (Cu1), $\mathrm{Cu} 1 \mathrm{mM}$ (Cu2), Cu $1.5 \mathrm{mM}$ (Cu3), 20\% PEG+Cu $0.5 \mathrm{mM}$ (D+Cu1), 20\% PEG+Cu $1 \mathrm{mM}$ (D+Cu2), 20\% PEG+Cu $1.5 \mathrm{mM}$ $(\mathrm{D}+\mathrm{Cu} 3)$. Columns with different letters are significantly different $(\mathrm{P}<$ $0.05)$ values 
367

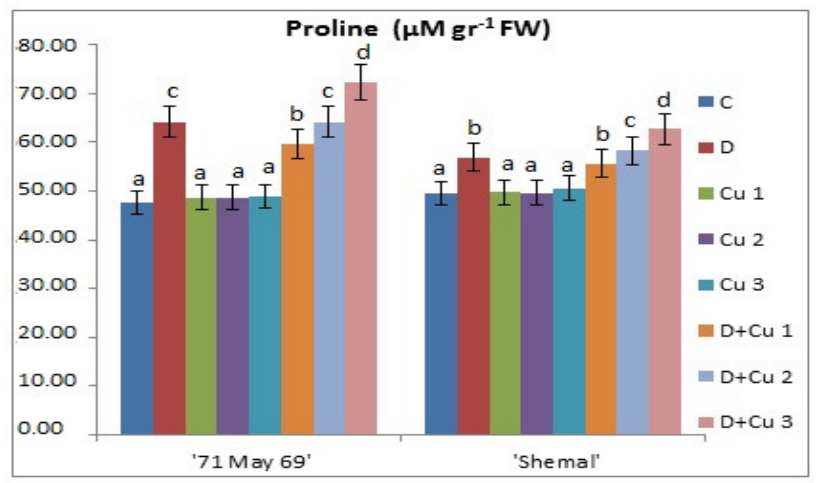

Fig. 5. Effects of copper treatment under drought stress on proline content tolerant '71May69' and sensitive 'Shemal' maize (Zea mays) cultivars. Control group (C), 20\% PEG (D), Cu 0.5 mM (Cu1), Cu 1 $\mathrm{mM}$ (Cu2), Cu $1.5 \mathrm{mM}$ (Cu3), 20\% PEG+Cu $0.5 \mathrm{mM}$ (D+Cu1), 20\% PEG+Cu $1 \mathrm{mM}$ (D+Cu2), 20\% PEG+Cu $1.5 \mathrm{mM}$ (D+Cu3). Columns with different letters are significantly different $(\mathrm{P}<0.05)$ values

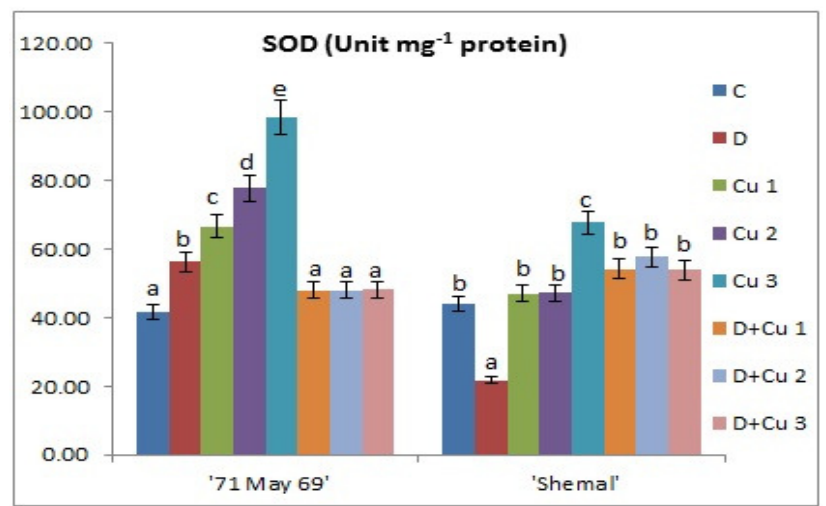

Fig. 6. Effects of copper treatment under drought stress on superoxide dismutase (SOD) enzyme activity in tolerant '71May 69' and sensitive 'Shemal' maize (Zea mays) cultivars. Control group (C), 20\% PEG (D), $\mathrm{Cu} 0.5 \mathrm{mM}$ (Cu1), Cu 1 mM (Cu2), Cu 1.5 mM (Cu3), 20\% PEG+Cu $0.5 \mathrm{mM}$ (D+Cu1), 20\% PEG+Cu $1 \mathrm{mM}$ (D+Cu2), 20\% $\mathrm{PEG}+\mathrm{Cu} 1.5 \mathrm{mM}(\mathrm{D}+\mathrm{Cu} 3)$. Columns with different letters are significantly different $(\mathrm{P}<0.05)$ values

induced SOD activity more in tolerant maize cultivar. Also, Fidalgo et al. (2013) determined unchanged SOD activity under lower copper treatment in Solanum nigrum. In Sgherri et al. (2001) report, SOD did not change in wheat leaves under sub-sypmtomatic copper doses. It was also previously observed in $\mathrm{Cu}$-treated seedlings (Palma et al., 1984). However, combined treatment increased SOD enzyme and isoenzyme activity in Shemal under all concentrations while it was decreased in '71MAY69' (Fig. 6a, 6b). Thounaojam et al. (2012) reported that SOD induced under copper treatment in rice shoots, but it could be changed by difference in concentrations. These differences could be originated in different sensitivities in response to copper in maize leaves. According to the results, it could be suggested that copper treatment protected the sensitive leaves from drought-induced damage by increasing SOD activity according to PEG treatment alone, but 1.5 mM Cu was not subsymptomatic for 'Shemal' (Fig. 6).
CAT activity increased in tolerant cultivar (41.5\%), but decreased $(33.8 \%)$ in sensitive one under PEG treatment alone according to the control groups. In accordance with this result, Chung et al. (2011) determined that CAT activity increased in tolerant maize and decreased in sensitive one under stress. This result is also in agreement with the result of hydrogen peroxide, which had been increased under PEG treatment in both cultivars. CAT is an important enzyme, which could scavenge hydrogen peroxide in plant cell (Li et al., 2009). The decrease in SOD and CAT activity leads to increase in $\mathrm{H}_{2} \mathrm{O}_{2}$ content, especially in sensitive leaves. With regard to copper treatment, there was increase in CAT activity of both cultivars according to the control group (Fig. 7). Similarly, Posmyk et al. (2009) and Brahim and Mohamed (2001) observed that copper treatment induced CAT activity in red cabbage and Atriplex halimus. In contrast, some papers indicated that this metal inhibited CAT acitivity in Brassica junicea (Wang et al., 2004) and sunflower (Jouli and El Feriani, 2003). However, in our results, combined treatment induced CAT activity according to PEG treatment alone in both cultivars. It could be clearly observed that copper could induce CAT activity more under combined treatment than PEG induced alone. This result showed that copper treatment plays a role for inducing antioxidant enzymes, which is independent of its tolerant to drought stress. PEG treatment alone did not change APX activity in '71MAY69', but decreased in 'Shemal' according to the control groups (Fig. 8). In the previous studies, APX activity increased in drought-tolerant bentgrass (DaCosta and Huang, 2007). Similarly, an increase in APX activity was observed in drought-stressed rice seedlings. In this study, the decrease in APX activity could lead to higher hydrogen peroxide in sensitive maize leaves, while it was less in tolerant ones. Otherwise, copper treatment alone induced APX activity in both cultivars (45.6\% and $41.9 \%$ ) when compared with the control group, but did not change into each other (Fig. 8). Similarly, Tewari et al. (2006) and Andrade et al. (2010) reported the enhancement of APX activity under copper stress. This could be related with unchanged hydrogen peroxide and MDA content under copper treatment. Like CAT activity results, combined treatment increased APX activity according to PEG treatment alone in both cultivars, but this increase was higher in sensitive cultivar (Fig. 8). As a result, APX activity was more effective under copper treatment according to PEG treatment. As in SOD, CAT activity, APX was also effective for detoxifying the hydrogen peroxide content. Otherwise, only SOD activity was effective depending on $\mathrm{Cu}$ concentrations.

Glutathione reductase activity is one of the important antioxidant enzymes for detoxifying ROS (Yousuf et al. 2012). As a result, PEG induced GR activity according to the control group '71MAY69', while it was not changed in 'Shemal' (Fig. 9). Parallel to our results, GR activity increased under drought stress in sensitive Hibiscus esculentus L. cultivars (Kusvuran, 2012). With regard to copper treatments, the highest increase was under $1.5 \mathrm{mM}$ concentrations. Similarly, Tanyolaç et al. (2007) reported that $1.5 \mathrm{mM}$ concentration induced GR activity in maize plants. Otherwise, combined treatment induced GR activity 


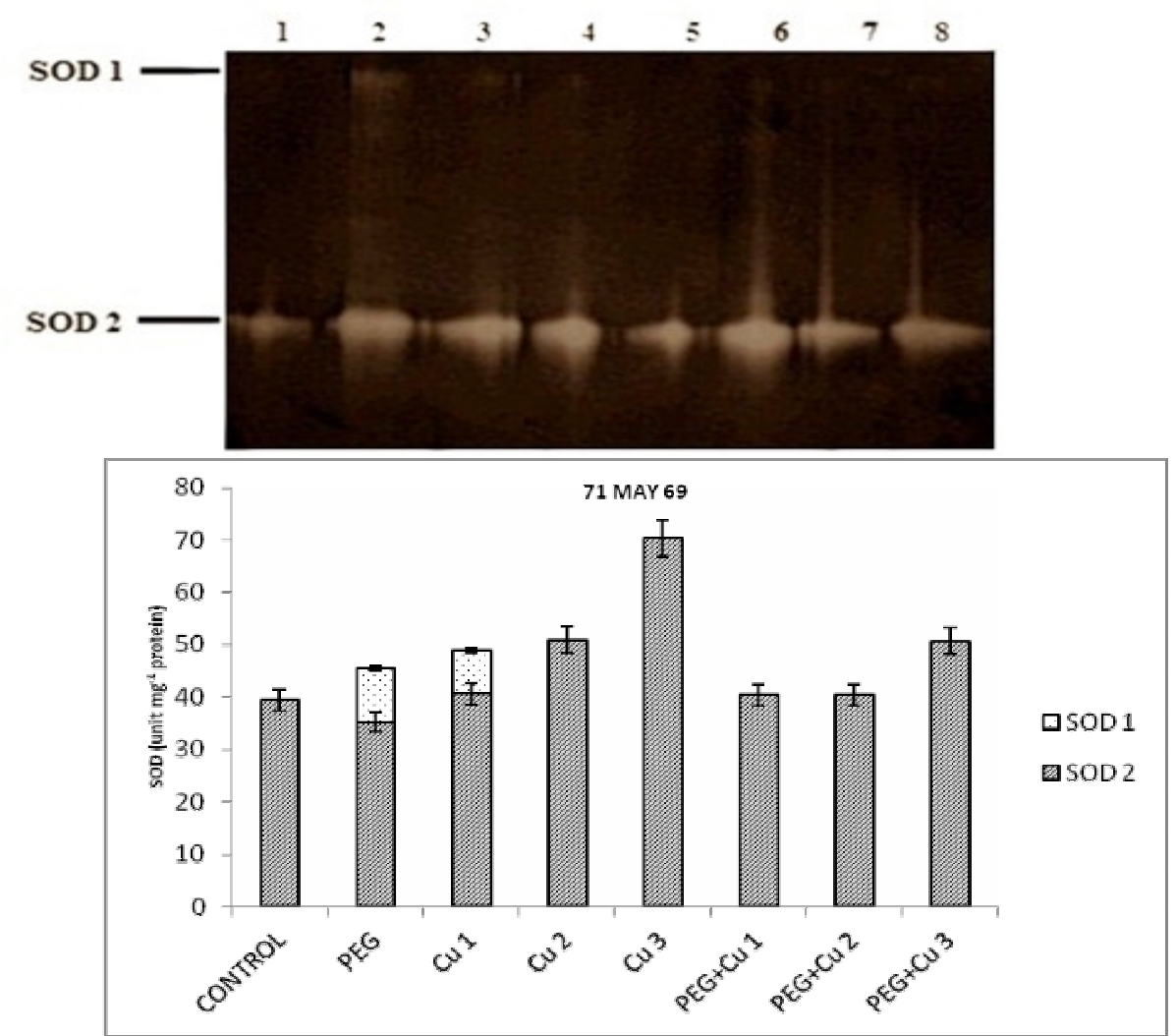

Fig. 6a. Activity staining and \% induction of SOD isoenzymes in tolerant '71May69' maize (Zea mays) cultivars. Control group (C), 20\% PEG (D), Cu 0.5 mM (Cu1), Cu 1 mM (Cu2), Cu 1.5 mM (Cu3), 20\% PEG+Cu 0.5 mM (D+Cu1), 20\% PEG+Cu 1 $\mathrm{mM}(\mathrm{D}+\mathrm{Cu} 2), 20 \% \mathrm{PEG}+\mathrm{Cu} 1.5 \mathrm{mM}(\mathrm{D}+\mathrm{Cu} 3)$

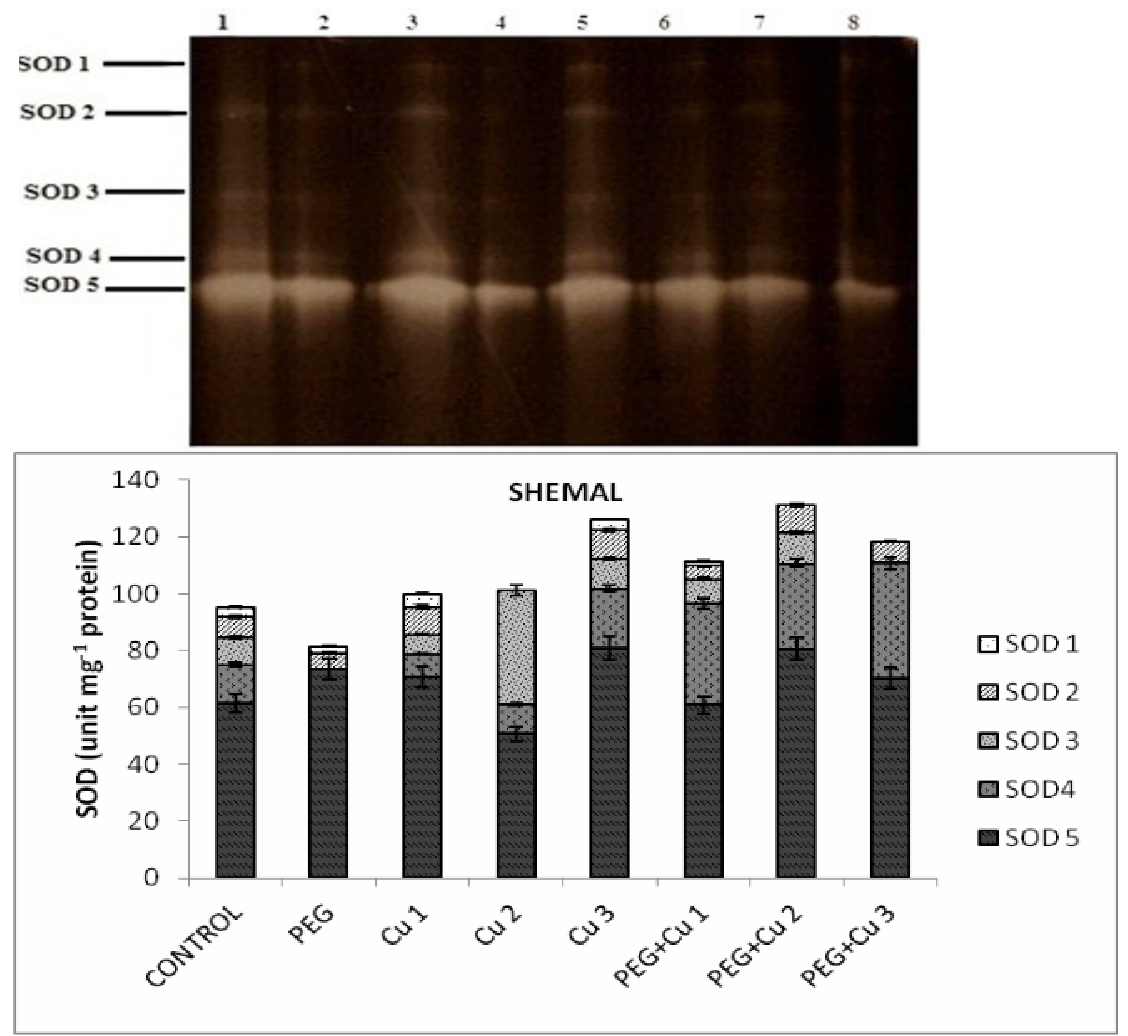

Fig. 6b. Activity staining and \% induction of SOD isoenzymes in sensitive 'Shemal' maize (Zea mays) cultivars. Control group (C), 20\% PEG (D), Cu 0.5 mM (Cu1), Cu 1 mM (Cu2), Cu 1.5 mM (Cu3), 20\% PEG+Cu 0.5 mM (D+Cu1), 20\% PEG+Cu 1 $\mathrm{mM}(\mathrm{D}+\mathrm{Cu} 2), 20 \% \mathrm{PEG}+\mathrm{Cu} 1.5 \mathrm{mM}(\mathrm{D}+\mathrm{Cu} 3)$ 
369

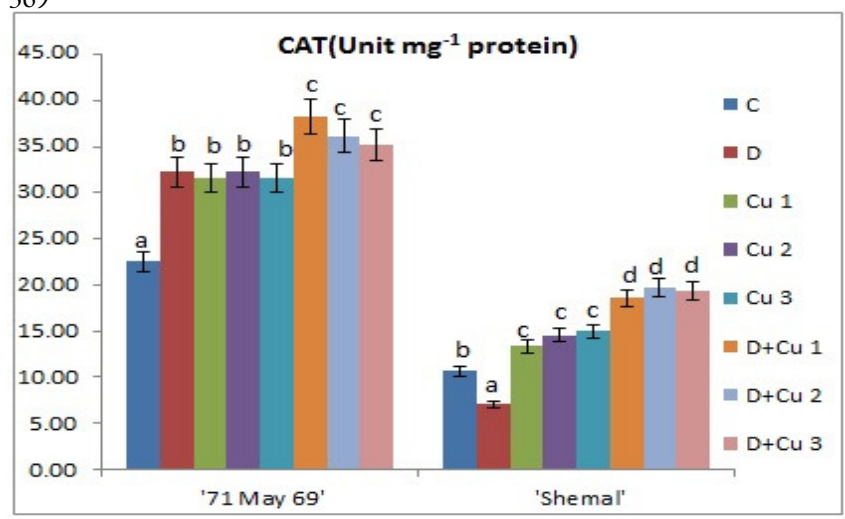

Fig. 7. Effects of copper treatment under drought stress on catalase (CAT) enzyme activity in tolerant '71May69' and sensitive 'Shemal' maize (Zea mays) cultivars. Control group (C), 20\% PEG (D), Cu 0.5 mM (Cu1), Cu 1 mM (Cu2), Cu $1.5 \mathrm{mM}$ (Cu3), 20\% PEG+Cu $0.5 \mathrm{mM}(\mathrm{D}+\mathrm{Cu} 1), 20 \%$ $\mathrm{PEG}+\mathrm{Cu} 1 \mathrm{mM}(\mathrm{D}+\mathrm{Cu} 2), 20 \% \mathrm{PEG}+\mathrm{Cu} 1.5 \mathrm{mM}(\mathrm{D}+\mathrm{Cu} 3)$. Columns with different letters are significantly different $(\mathrm{P}<$ $0.05)$ values

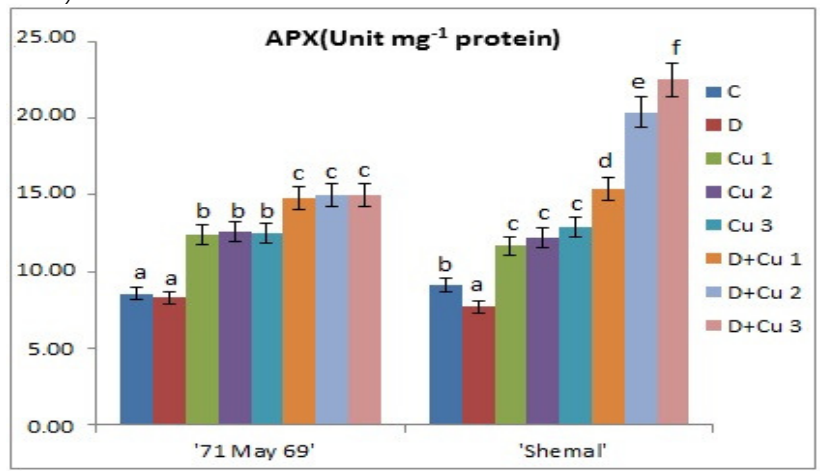

Fig. 8. Effects of copper treatment under drought stress on ascorbate peroxidase (APX) enzyme activity in tolerant '71May69' and sensitive 'Shemal' maize (Zea mays) cultivars. Control group (C), 20\% PEG (D), Cu 0.5 mM (Cu1), Cu 1 mM (Cu2), Cu 1.5 mM (Cu3), 20\% $\mathrm{PEG}+\mathrm{Cu} 0.5 \mathrm{mM}$ (D+Cu1), 20\% PEG+Cu $1 \mathrm{mM}$ (D+Cu2), 20\% $\mathrm{PEG}+\mathrm{Cu} 1.5 \mathrm{mM}(\mathrm{D}+\mathrm{Cu} 3)$. Columns with different letters are significantly different $(\mathrm{P}<0.05)$ values

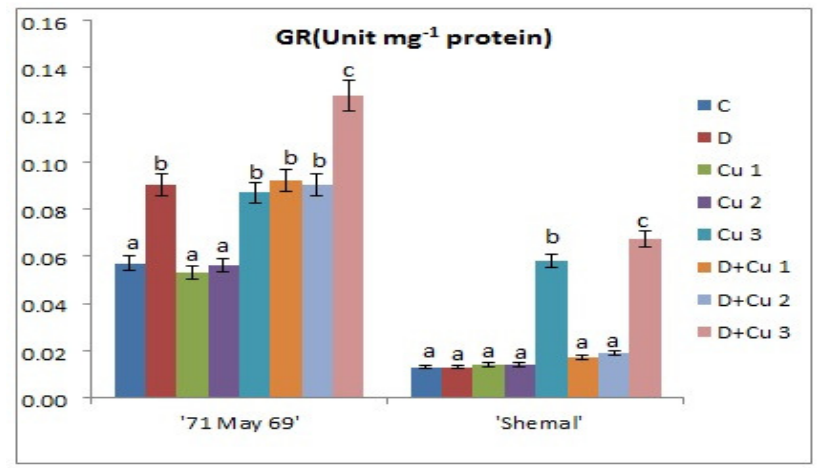

Fig. 9. Effects of copper treatment under drought stress on glutathione reductase (GR) enzyme activity in tolerant '71May69' and sensitive 'Shemal' maize (Zea mays) cultivars. Control group (C), 20\% PEG (D), Cu 0.5 mM (Cu1), Cu 1 mM (Cu2), Cu 1.5 mM (Cu3), 20\% PEG+Cu $0.5 \mathrm{mM}$ (D+Cu1), 20\% PEG+Cu $1 \mathrm{mM}$ (D+Cu2), 20\% $\mathrm{PEG}+\mathrm{Cu} 1.5 \mathrm{mM}(\mathrm{D}+\mathrm{Cu} 3)$. Columns with different letters are significantly different $(\mathrm{P}<0.05)$ values

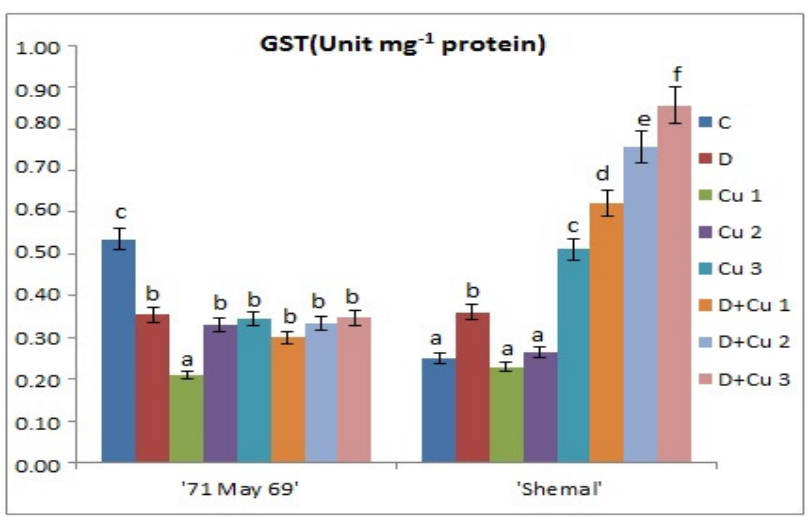

Fig. 10. Effects of copper treatment under drought stress on glutathione $S$-transferase (GST) enzyme activity in tolerant '71May69' and sensitive 'Shemal' maize (Zea mays) cultivars. Control group (C), 20\% PEG (D), Cu 0.5 mM (Cu1), Cu $1 \mathrm{mM}$ (Cu2), Cu $1.5 \mathrm{mM}$ (Cu3), 20\% PEG+Cu 0.5 mM (D+Cu1), \%20 PEG+Cu 1 $\mathrm{mM}(\mathrm{D}+\mathrm{Cu} 2), 20 \% \mathrm{PEG}+\mathrm{Cu} 1.5 \mathrm{mM}$ (D+Cu3). Columns with different letters are significantly different $(\mathrm{P}<0.05)$ values

according to PEG treatment alone in both cultivars $(42.2 \%$ and 5.1 fold) (Fig. 9). Glutathione $S$-transferases (GST, EC 2.5.1.18), a group of dimeric, multifunctional enzymes, catalyze conjugation of glutathione $(\mathrm{GSH})$ with xenobiotic compounds for detoxification (Tausz et al., 2004). In this work, GST enzyme activity increased in 'Shemal' by PEG treatment but decreased in cv. '71MAY69', when compared with the control samples (Fig. 10). Csiszár et al. (2007) also reported that GST activity increased with decreasing water content in Allium sp. Copper treatment alone reduced the GST activity in '71MAY69', but it increased under highest copper concentration $(1.5 \mathrm{mM})$ in cv. 'Shemal' according to the control samples. These findings showed that only the highest concentration could be achieved to induce GST activity in maize leaves. Similar to our results, there was no change in GST activity observed in wheat seedlings (Gajewska and Sklodowska, 2005). Combined treatment increased GST activity (PEG+ $1.5 \mathrm{mM}$ copper treatment, 2.4 fold) when compared with PEG treatment alone in 'Shemal', while it did not change in '71MAY69'. From this result, it could be suggested that GST enzyme activity did not change in '71MAY69' for its tolerant capacity against drought stress.

\section{Conclusions}

Collectively, our results showed that copper concentration did not cause oxidative damage in maize leaves, but it could alleviate the drought-induced oxidative damage, especially in sensitive cultivar. Otherwise, SOD, APX, CAT, and GR enzyme activities were induced by copper treatment alone, while they reduced under PEG treatment alone. The increase in enzyme activity under PEG treatment could be explained by endogenous ABA accumulation, but it is not the same with copper treatment because there was no change in ABA, hydrogen peroxide, proline content and MDA level. It could be suggested that there could be another signal mechanism to induce enzyme activities with copper. These findings determined that 
copper response of plants is not a common signal but specific in maize leaves. Exogenous copper alleviated drought stress induced oxidative damage by increasing antioxidant enzyme activities by different signals from drought tolerance.

\section{References}

Alaoui-Sossé B, Genet P, Vinit-Dunand F, Toussaint ML, Epron D, Badot PM (2004). Effect of copper on growth in cucumber plants (Cucumis sativus) and its relationships with carbohydrate accumulation and changes in ion contents. Plant Sci 166(5):12131218.

Andrade SAL, Gratão PL, Azevedo RA, Silveira APD, Schiavinato MA, Mazzafera P (2010). Biochemical and physiological changes in jack bean under mycorrhizal symbiosis growing in soil with increasing Cu concentrations. Environ Exp Bot 68:198-207.

Beauchamp C, Fridovich I (1971). Superoxide dismutase: improved assays and an assay applicable to acrylamide gels. Anal Biochem 44:276-287.

Bergmeyer HU (1970). Methods of enzymatic analysis. AkademieVerlag, Berlin, Germany 1:636-647.

Brahim L, Mohamed M (2001). Effects of copper stress on antioxidative enzymes, chlorophyll and protein content in Atriplex halimus. AfrJ Biotechnol 10(50):10143-10148.

Bright J, Desikan R, Hancock JT, Weir IS, Neill SJ (2006). ABAinduced $\mathrm{NO}$ generation and stomatal closure in Arabidopsis are dependent on $\mathrm{H}_{2} \mathrm{O}_{2}$ synthesis. Plant J 45:113-122.

Chen CT, Chen LM, Lin CC, Kao CH (2001). Regulation of proline accumulation in detached rice leaves exposed to excess copper. Plant Sci 160:283-290.

Chung V, Kaur N, Gupta AK (2011). Evaluation of oxidative stress tolerance in maize (Zea mays $\mathrm{L}$.) seedlings in response to drought. Indian J Biochem Bio 48:47-53.

Claussen W (2005). Proline as a measure of stress in tomato plants. Plant Sci 168:241-248.

Csiszár J, Lantos E, Tari I, Madoşă E, Wodala B, Vashegyi Á, Horváth F, Pécsváradi A, Szabó M, Bartha B, Gallé Á, Illés E, Lazăr A, Coradini G, Staicu M, Postelnicu S, Mihacea S, Nedelea G, Erdei L (2007). Antioxidant enzyme activities in Allium species and their cultivars under water stress. Plant Soil Environ 53:511-516.

DaCosta M, Huang B (2007). Changes in antioxidant enzyme activities and lipid peroxidation for bentgrass species in response to drought.J Am Soc Hortic Sci 132:319-326.

Droppa M, Horváth G (1990). The role of copper in photosynthesis. CRC Plant Sci 9:111-123.

Fidalgo F, Azenha M, Silva AF, Sousa A, Santiago A, Ferraz P, Teixeira J (2013). Copper-induced stress in Solanum nigrum L. and antioxidant defense system responses. Food and Energy Security 2(1):70-80.

Flores MIA, Romero-Gonzalez R, Garrido Frenich A, Luis Martinez Vidal J (2011). QuEChERS-based extraction procedure for multifamily analysis of phytohormones in vegetables by UHPLCMS/MS. J Sep Sci 34:1517-1524.
Foyer CH, Halliwell B (1976). Presence of glutathione and glutathione reductase in chloroplasts: a proposed role in ascorbic acid metabolism. Planta 133:21-25.

Fridovich I (1975). Superoxide dismutase. Annu Rev Biochem 44: 147-59.

Gaetke LM, Chow CK (2003). Copper toxicity, oxidative stress, and antioxidant nutrients. Toxicol 189:147-163.

Gajewska E, Skłodowska M (2005). Antioxidative responses and proline level in leaves and roots of pea plants subjected to nickel stress. Acta Physiol Plant 27:329-340.

Garcia-Mata C, Lamattina L (2007). Abscisic acid (ABA) inhibits light-induced stomatal opening through calcium- and nitric oxide-mediated signaling pathways. Nitric Oxide 17(3):143-151.

Gill SS, Tuteja N (2010) Reactive oxygen species and antioxidant machinery in abiotic stress tolerance in crop plants. Plant Physiol Bioch 48(12): 909-930.

Gunes A, Pilbeam D, Inal A, Coban S (2008). Influence of silicon on sunflower cultivars under drought stress. I. Growth, antioxidant mechanisms and lipid peroxidation. Commun Soil Sci Plant Nut 39:1885-1903.

Habig WH, Pabst MJ. Jakoby WB (1974). Glutathione $S$ transferases: the first enzymatic step in mercapturic acid formation. J Biol Chem 249:7130-7139.

Hall JL (2002). Cellular mechanism of heavy metal detoxification and tolerance. J Exp Bot 53(366):1-11.

Hanlon E (1998). Elemental determination by AAS. Yash P. Kaira, Handbook of Reference Methods for Plant Analysis. CRS Press, USA, pp. 157-165.

Hoagland D, Arnon D (1950). The water-culture method for growing plants without soil. Calif Agric Exp Stn Circ 347:1-32.

Hossain MA (2013). Heat-shock positively modulates oxidative protection of salt and drought-stressed mustard (Brassica campestris L.) seedlings. J Plant Sci Molecul Breed 4(7):50-70.

Jouili H, Ferjani EE (2003). Changes in antioxidant and lignifying enzyme activities in sunflower roots (Helianthus annuus L.) stressed with copper excess. Comptes Rendus Biologies 326:639644.

Kacar B, Inal A (2008). Plant analysis. Nobel publication, Ankara.

Kastori R, Maksimović I, Kraljević-Balalić M, Kobiljski B (2008). Physiological and genetic basis of plant tolerance of excess boron. Matica Srpska Proceedings for Natural Sciences 114:41-51.

Kramer PJ, Boyer JS (1995). Water relations of plants and soils. San Diego, Academic Press, 495.

Ku HM, Tan CW, Su YS, Chiu CY, Chen CT, Jan FJ (2012). The effect of water deficit and excess copper on proline metabolism in Nicotiana benthamiana. Biol Plant 56:337-343.

Kusvuran S (2012). Influence of Drought Stress on Growth, Ion Accumulation and Antioxidative Enzymes in Okra Genotypes. Int J Agric Biol 14(3):401-406.

Laemmli UK (1970). Cleavage of Structural Proteins during the Assembly of the Head of Bacteriophage T4. Nature 227:680-685.

Li Y, Song YP, Shi GJ, Wang JJ, Hou XL (2009). Response of antioxidant activity to exces coper in two cultivars of Brassica 
371

campestris sp.chinensis Makino. Acta Physiol Plant 31(1):5-162.

Madhava RKV, Sresty TVS (2000). Antioxidative parameters in the seedlings of pigeon pea (Cajanus cajan L. millspaugh) in response to $\mathrm{Zn}$ and Ni stresses. Plant Sci 157:113-12.

Nakano Y, Asada K (1981). Hydrogen peroxide is scavenged by ascorbate specific peroxidase in spinach chloroplasts. Plant Cell Physiol 22:867-880.

Ouzounidou G, Ciamporova M, Moustakas M, Karataglis S (1995). Responses of maize (Zea mays L.) plants to copper stress. I. Growth, mineral content and ultrastructure of roots. Environ Exp Bot 35:167-176.

Palma JM, Gomez M, Yan J, Del Rio LA (1987). Increased levels of peroxisomal active oxygen related enzymes in copper-tolerant pea plants. Plant Physiol 85:570-574.

Perez-Perez JG, Syvertsen JP, Botia P, Garcia-Sanchez F (2007). Leaf water relations and net gas exchange responses of salinized carrizo citrange seedlings during drought stress and recovery. Ann Bot 100:335-345.

Posmyk MM, Kontek R, Janas KM (2009). Antioxidant enzymes activity and phenolic compounds content in red cabbage seedlings exposed to copper stress. Ecotoxicol and Environ Safe 72:596602.

Rama Devi S, Prasad MNV (1998). Copper toxicity in Ceratophyllum demersum L. (Coontail), a free floating macrophyte: Response of antioxidant enzymes and antioxidants. Plant Sci 138:157-165.

Reddy AR, Viswanatha K, Vivekanandan CM (2004). Droughtinduced responses of photosynthesis and antioxidant metabolism in higher plants. J Plant Physiol 161:1189-1202.

Sgherri CLM, Milone AMT, Clijsters H, Navari-Izzo F (2001). Antioxidative enzymes in two wheat cultivars, differently sensitive to drought and subjected to subsymptomatic copper doses. J Plant Physiol 158:1439-1447.

Shinozaki K, Yamaguchi-Shinozaki K (2000). Molecular responses to dehydration and low temperature: differences and cross-talk between two stress signaling pathways. Curr Opin Plant Biol 3:217-223.
Smart RE, Bingham GE (1974). Rapid estimates of relative water content. Plant Physiol 53:258-260.

Socias X, Correia MJ, Chaves MM, Medrano H (1997). The role of abscisic acid and water relations in drought responses of subterranean clover. J Exp Bot 48:1281-1288.

Tanyolac D, Ekmekci Y, Unalan S (2007). Changes in photochemical and antioxidant enzyme activities in maize (Zea mays L.) leaves exposed to excess copper. Chemosphere 67:89-98.

Tausz M, Sircesj H, Grill D (2004). The glutathione system as a stress marker in plant ecophysiology: is a stress-response concept valid. J Exp Bot 55:1955-1962.

Tewari RK, Kumar P, Sharma PN (2006). Antioxidant responses to enhanced generation of superoxide anion radical and hydrogen peroxide in the copper-stressed mulberry plants. Planta 223:11451153.

Thounaojam TC, Panda P, Mazumdar P, Kumar D, Sharma GD, Sahoo L, Panda SK (2012). Excess copper induced oxidative stress and response of antioxidants in rice. Plant Physiol Biochem 53:3339.

Velikova V, Yordanov I, Edreva A (2000). Oxidative stress and some antioxidant systems in acid rain-treated bean plants: protective roles of exogenous polyamines. Plant Sci 151:59-66.

Wang SH, Yang ZM, Yang H, Lu B, Li SQ, Lu YP (2004). Copperinduced stress and antioxidative responses in roots of Brassica juncea L. Bot Bull Acad Sin 45:203-212.

Yousuf PY, Hakeem KUR, Chandna R, Ahmad P (2012). Role of glutathione reductase in plant abiotic stress. In: Ahmad P, Prasad MNV (Eds.). Towards the: Abiotic Stress Responses in Plants, pp: 149-158. Springer New York, Dordrecht, Heidelberg, London.

Yruela I (2005). Coper in Plants. Braz J Plant Physiol 17(1):145-156.

Zengin FK, Kirbag S (2007). Effects of copper on chlorophyll, proline, protein and abscisic acid level of sunflower (Helianthus annuus L.) seedlings. J Environ Biol 28:561-566. 